\title{
Hemoperitoneum: a diagnostic dilemma. A solid ovarian tumour mimicking ruptured ectopic pregnancy
}

\author{
Wills G. Sheelaa*, Jayasree Manivasakan
}

Department of Obstetrics \& Gynaecology, Sri Manakula Vinayagar Medical College and Hospital (SMVMCH), Puducherry- 605 107, India

Received: 9 April 2013

Accepted: 14 April 2013

*Correspondence:

Dr. Wills G. Sheelaa,

E-mail: drgwilissheelaa@gmail.com

(C) 2013 Sheelaa WG et al. This is an open-access article distributed under the terms of the Creative Commons Attribution License, which permits unrestricted use, distribution, and reproduction in any medium, provided the original work is properly cited.

\section{ABSTRACT}

39 year old sterilized women presented like ruptured ectopic pregnancy with 40 days amenorrhea, pain, and shock Urine Pregnancy Test negative. Culdocentesis was positive. Ultra sonogram confirmed hemoperitoneum and TO mass. Laparotomy revealed left solid ovarian tumour with tumour mass protruding from perforated site and hemoperitoneum. Histological diagnosis was granulosa cell (GC) tumour Stage 1c.

Keywords: Hemoperitoneum, Solid ovarian tumour

\section{INTRODUCTION}

Hemoperitoneum is one of the life threatening situations when women present with acute abdomen pain and shock, necessitating high levels suspicion of diagnosis and active intervention. Granulosa cell (GC) tumors accounts for $2 \%$ of all ovarian tumors. Lee et al. reported that preoperative rupture occurred in $17.6 \%$ of granulosa cell tumors. ${ }^{1}$ They are derived from sex cords and mesenchyma of the ovary, which contain granulosa cells, theca cells and fibroblasts. They have low malignancy potential.

\section{CASE REPORT}

39 year old $\mathrm{P}_{2} \mathrm{~L}_{2}$ sterilized women presented with 40 days amenorrhea abdominal pain, vomiting, pallor and shock. Hemoglobin was $7 \mathrm{gm} / \mathrm{dL}$. Abdomen was distended with fluid thrill and tenderness in suprapubic region. A mass of about 16-18 week size of uterus, with restricted movement was palpable per abdomen. There was no bleeding per vaginum. Cervix was in mid position. Exact size of uterus could not be made out. A solid mass of 20 week size arising from left fornix was felt. Pregnancy test was negative. Culdocentesis was positive. Ultra sonogram revealed a mid line mixed echogenic mass of size 14.6 into $9.2 \mathrm{~cm}$ arising from pelvis. Both ovaries could not be visualized. There was fluid in pouch of Douglas. A diagnosis of ruptured ovarian cyst was made. Emergency laparotomy was proceeded with.

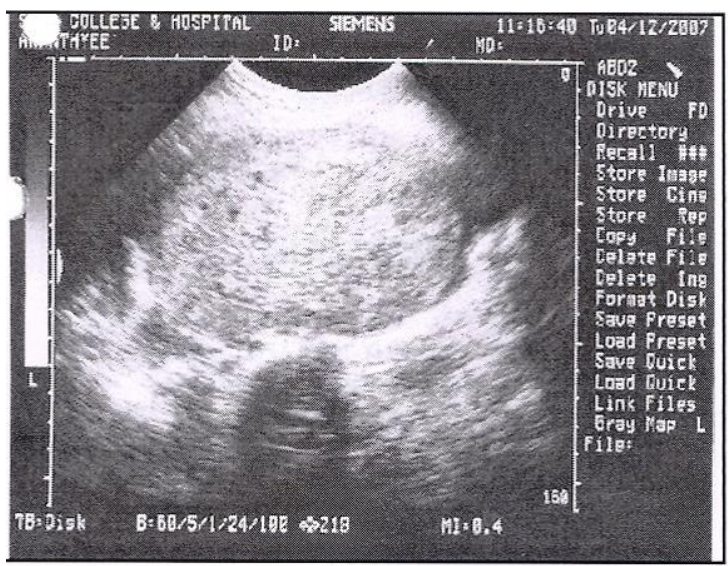

Figure 1: USG picture of GC tumour. 


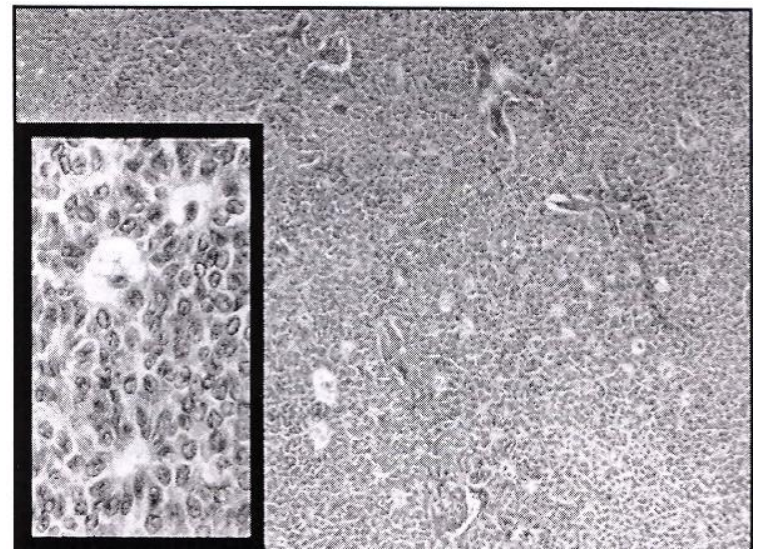

Figure 2: Histological picture.

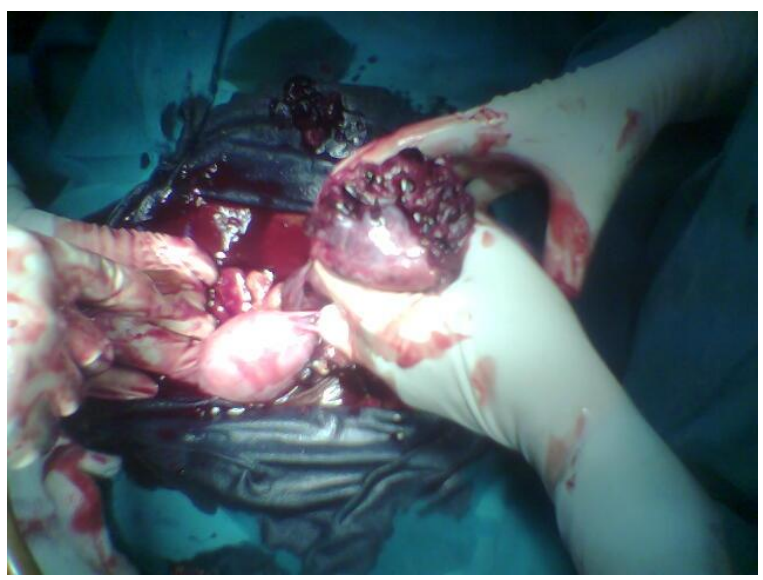

Figure 3: Site of rupture.

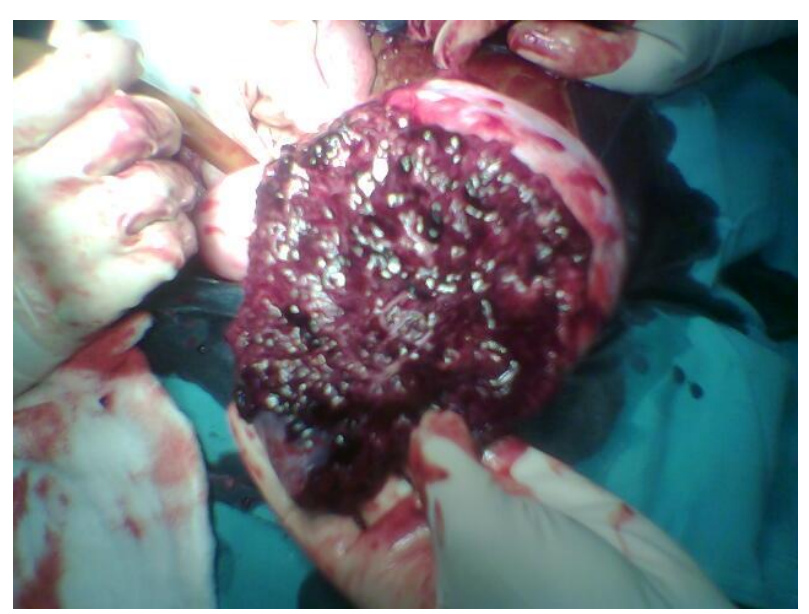

Figure 4: Gross appearance of tumour.

On opening the abdomen there was about $1500 \mathrm{ml}$ of blood stained fluid and $50 \mathrm{gm}$ clot. Uterus was bulky. Both tubes were normal. Left ovary was enlarged to 18 weeks size of uterus, solid in consistency. There was a rent of size $4 \mathrm{~cm} \times 3 \mathrm{~cm}$ at the lower lateral end of the tumour, from which the tumour mass was protruding. Total abdominal hysterectomy, left salpingooophorectomy, right salpingo ovariotomy and omental biopsy was done. Abdomen was explored. There were no obvious peritoneal deposits and enlarged lymph nodes. Two units of B+ve blood were transfused. Post operative period was uneventful. Patient was discharged on the $9^{\text {th }}$ postoperative day.

Histology showed stage Ic granulosa cell tumor with evidence of rupture and pericapsular extension. Tumor is chemo sensitive and estrogen producing. Both tubes and right ovary were normal. Simple cystic hyperplasia of endometrium and adenomyosis of the myometrium were other histological features. The woman was referred to higher centre for chemotherapy.

\section{DISCUSSION}

Hemoperitoneum is an emergency situation where there is intraperitoneal bleeding, needing accurate diagnosis and active intervention. The commonest gynecological cause is ruptured ectopic pregnancy. A review of literature on rare cases of hemoperitoneum mimicking ectopic pregnancy is discussed. Hemoperitoneum due to tubal abortion in a woman with negative pregnancy test is reported by KaYuTse. ${ }^{2}$ Hemoperitoneum due to perforation of invasive mole was reported by Sunesh ${ }^{3}$ and Anuradha. ${ }^{4}$ Powell Martin has published a case with clinical dilemma where a woman presented with spontaneous hemoperitoneum caused by gangrenous bowel due to post operative adhesions of hemorrhagic ovarian cyst. ${ }^{5}$ Massive hemoperitoneum from bleeding endometriotic nodule was reported by Mutihir from Nigeria. ${ }^{6}$

\section{CONCLUSION}

Granulosa cell tumors comprise $10 \%$ of solid ovarian tumors which are unilateral and encapsulated. These are feminizing functioning mesenchymomas. A rare case of ruptured solid ovarian tumour with histological diagnosis of granulosa cell tumour, mimicking ruptured ectopic pregnancy is presented here for its unusual presentation, diagnostic dilemma and surprise intraoperative findings. High index of suspicion is imperative to avoid delay in diagnosis and management.

\section{ACKNOWLEDGEMENTS}

The authors thank Prof. S. Sowmya, Dept. of Pathology, SMVMCH for providing histopathological report.

\author{
Funding: None \\ Competing interests: None declared \\ Ethical approval: Not required
}

\section{REFERENCES}

1. Lee IH, Choi CH, Hong DG, Song JY, Kim YJ, Kim KT, Lee KW, Park IS, Bae DS, Kim TJ. Clinicopathologic characteristics of granulosa cell 
tumors of the ovary: a multicenter retrospective study. J Gynecol Oncol 2011;22:188-95.

2. KY Tse, WC Leung, NT Lau, CT Lau. Haemoperitoneum due to tubal abortion in a patient with negative urine pregnancy test. Case report and literature review. Hong Kong J Gynaecol Obstet Midwifery 2006;6:45-8.

3. Suneshkumar, Vimale N, Mittal S. Invasive mole presenting as acute haemoperitoneum. JK Science 2004;6:159-60.

4. De A, Sinha A, Seal SL, Battachariya AR, Pramanik SR. An unusual presentation of choriocarcinoma mimicking ruptured ectopic pregnancy with fulminant progression. J Obstet Gynaecol India 2007;57:540-1.

5. Palep- Singh M, Matani B, Powell M. Spontaneous hemoperitoneum: a clinical dilemma. J Obstet Gynaecol India 2009;59:481-2.

6. Mutihir JT, Nyango DD. Massive haemoperitoneum from endometriosis masquerading as ruptured ectopic pregnancy: case report. Niger J Clin Pract 2010;13:477-9.

DOI: $10.5455 / 2320-1770 . i j r \operatorname{cog} 20130635$

Cite this article as: Sheelaa WG, Manivasakan J. Hemoperitoneum: a diagnostic dilemma. A solid ovarian tumour mimicking ruptured ectopic pregnancy. Int J Reprod Contracept Obstet Gynecol 2013;2:254-6. 